\title{
形式オントロジーと順序ソート論理の拡張*
}

\section{Formal Ontology and Extensions of Order-Sorted Logic}

\author{
兼岩 憲国立情報学研究所情報学基礎研究系 \\ Ken Kaneiwa $\quad$ Foundations of Information Research Division, National Institute of Informatics \\ kaneiwa@nii.ac.jp, http://research.nii.ac.jp/ kaneiwa/ \\ $\underset{\text { Riichiro Mizoguchi }}{\text { 煹口郎 }}$ \\ 大阪大学産業科学研究所 \\ The Institute of Scientific and Industrial Research, Osaka University \\ miz@ei.sanken.osaka-u.ac.jp, http://www.ei.sanken.osaka-u.ac.jp/
}

keywords: formal ontology, order-sorted logic, ontological property classification, rigidity

\section{Summary}

This paper presents several extensions of order-sorted logic based on the notion of property classification in formal ontology. The refined order-sorted language contains types (as rigid sorts), anti-rigid sorts, and unary predicates in order to distinctly express the following properties: substantial sorts, nonsubstantial sorts, and non-sortal properties. For many separated knowledge bases constructed using the logic, we propose an enriched reasoning mechanism such that each independent knowledge base can extract rigid property information from other knowledge bases (called rigid property derivation). Additionally, we classify (i) anti-rigid properties on the basis of their dependences on time, situation, and belief and (ii) non-sortal properties on the basis of the countability of the elements of the properties.

\section{1. は じめ に}

順序ソート論理 [Oberschelp 62, Cohn 87, Weibel 97] は複数のソートと产の階層 (ソート階層と呼ゔ) を含む一

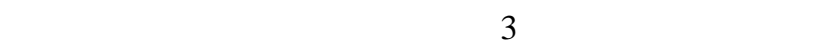
してくれる.1つ目は, 関数, 述語およひ変数の定義域や 值域の制限 (全体集合の部分集合)により，推論のための 検索空間が縮小されることである [Walther 85]. 2つ目 は, 一階述語論理のフラットな表現にはない , 半順序ソー 卜 (partially ordered sorts) による構造的な知識表現であ る [Cohn 89]. 人工知能の研究分野では, ソートを利用 することで 2 種類の知識表現 (言明と概念階層) をもつ論 理プログラミングや演繹システムの拡張が提案されてい る [Aït-Kaci 86, Kifer 95, Smolka 89, Cohn 89, Kaneiwa 04b]. さらに 3 つ目の優位性として, 型付きのプログラ ミング言語のように, 整合ソート論理式によるソートエ ラーの検出ができることが挙げられる . 例えば，「呼吸す

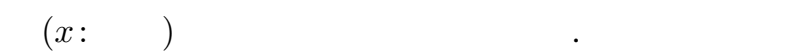
式「呼吸する $(1: i n t)\lrcorner$ は偽の論理式ではなく, ソートエ ラーを含む表現とみなされて排除される .ソートなしの論

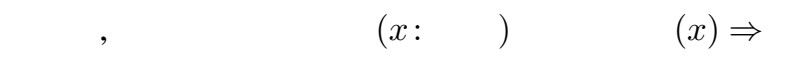
吸する $(x)\lrcorner て ゙$ 書き換えることができてもソートェラーは 検出できない．なぜならば，「動物 $(1) \Rightarrow$ 呼吸する $(1) 」$ 自体は整合論理式となってしまうからである.

\footnotetext{
* 本論文は, 文献 [Kaneiwa 04d] の内容を一部含んでいる .
}

ソート理論 [Beierle 92, Frisch 89]や制約論理では, ソー 卜階層内のサブソート関係 $s<s^{\prime}$ を同値な一階述語論理 の包含関係 $s(x) \Rightarrow s^{\prime}(x)$ で表す.このような变換は, 論 理的かつ意味論的にソートと単項述語が同一であること による.しかし形式オントロジーの分野では, ソートと 単項述語は共に個体集合としての property に対応する が, property は図 1 のようにソートと非ソート [Strawson 59, Lowe 89] に分類される [Guarino 94] . さらに , ソー 卜は本質属性 (例えば, リンゴ) と非本質属性 (例えば, 学 生)に細分化され，非ソートは普遍特性 (例えば, 水や空 気) と characterizing (例えば，赤い)に区別される. この ような property 分類は, 構造的知識の推論システムを構 築する際に , ソートと単項述語をどのように使い分けれ ばいいか重要な指針を与えてくれる．

しかしながら, これまで順序ソート論理の形式化には 形式オントロジーによる property 分類のアイデア (ソー トと非ソートの区別など) を取り込むアプローチはなさ れていない. また形式オントロジーの研究者は, property 分類のアイデアを論理に取り込んで新たな構文, 意味論 および推論システムを提案することには高い関心を持っ ていなかったようだ.

そこで本論文では, 形式オントロジーの property 分類 を導入することで, 順序ソート論理を拡張する試みを行 う.また，論理言語の考え方から property の特性を細か く分析する. 本論文で扱う項目は, 以下が挙げられる. 
表 1 タイプ,ソートおよび単項述語の rigidity

\begin{tabular}{|c|c|c|c|c|c|c|}
\hline property & \multicolumn{2}{|l|}{ 表現 } & \multicolumn{2}{|c|}{ インスタンス言明 } & \multicolumn{2}{|l|}{ 包摂関係 } \\
\hline 本質属性 & \multirow[b]{2}{*}{ ソート $s$} & タイプ $\tau$ & $\tau(t)$ & rigid & \multirow{2}{*}{\multicolumn{2}{|c|}{$\begin{array}{l}\tau_{1}<\tau_{2} \\
\sigma_{1}<\tau_{2} \\
\sigma_{1}<\sigma_{2}\end{array}$}} \\
\hline 非本質属性 & & 反 rigid ソート $\sigma$ & $\sigma(t)$ & 反 rigid & & \\
\hline 非ソート & \multicolumn{2}{|c|}{ 単項述語 $p$} & $p(t)$ & 非 rigid & $p_{1}(x) \Rightarrow p_{2}(x)$ & ある状況 \\
\hline
\end{tabular}

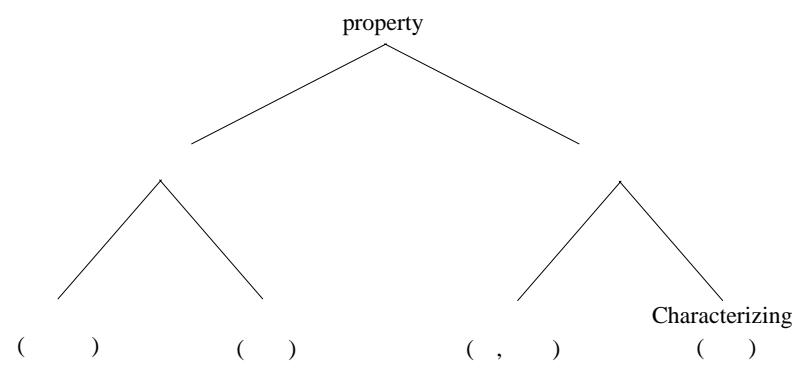

図 1 property の分類木 (a)

(1) 順序ソート論理

a 構文, 意味論および推論の再考

b property 名の関数と 2 項述語への拡張

(2) 形式オントロジー

a 時間/状況/信念の依存性

b 非本質属性の可能世界意味論による分類

c ソートと非ソートの分類

property 分類の考えを出発点として, 最初に順序ソート 論理の構文を再考し，光の言語を使って rigidity による 知識ベース上の推論を提案する．さらに，順序ソート論 理の意味論に従って, property の rigidity および依存性 を含んだ意味論を定義する．こうした論理的な拡張から， property 分類を細分化して, 形式オントロジーの結果が 得られる.

本論文の構成は, 次の通りである . 2 章では, 形式才 ントロジーの property 分類の考えを導入した順序ソート 論理の表現について述べる . 3 章は，2 章の言語によって 記述された知識ベース上の推論を説明する . 4 章は，順 序ソート論理の意味論とクリプケ意味論を組み合わせて , property 分類の意味解釈を行う . ここで異なる可能世界 の依存性や実体の可算性による property の細分化を行 う. 最後に, 5 章で研究のまとめと今後の課題について 述べる。

\section{2. property 分類と順序ソート 論理}

\section{$2 \cdot 1$ 順序ソート 論理}

順序ソート論理は, 複数のソート記号 $s, s_{1}, s_{2}, \ldots$ の 集合 $S$ とサブソート関係 $<$ の対 $(S,<)$ からなるソート 階層を導入した一階述語論理である . 各ソート記号は光 れぞれ限定されたドメインを表しており，次のサブソー 卜関係は,「学生」と「教師」が「人間」のサブソートで あることを示している．
学生 $<$ 人間，教師 $<$ 人間

ソート階層は, 従来はフラットな表現しか持たなかった述 語論理に構造的な表現をもたらす.このようなソート記号 を用いてソート項とソート論理式が定義される .ソート項 は, $x: s, c: s$ と $f\left(t_{1}, \ldots, t_{n}\right): s$ のようなソート付きの 変数, 定数およひ関数である (但し, $t_{i}$ はソート項である). 例えば， $x$ ：人間」は変数 $x$ がソート「人間」によって制限 されている項表現である .ソート論理式は, $p\left(t_{1}, \ldots, t_{n}\right)$, $A \wedge B, A \vee B, \neg A, A \Rightarrow B,(\forall x: s) A,(\exists x: s) A$ からな る表現である (但し,$t_{i}$ はソート項であり， $A, B$ はソー 卜論理式である $)$. 例えば,「赤い $(x:$ リンゴ $) 」$ は「リン ゴ $x$ は赤い」示すソート論理式である .

さらに, Beierle ら [Beierle 92] はソート階層と論理式 をより強く結びつけるために, ソートを単項述語(ソー 卜述語と呼ゔ）で用いることを許している . 例えば , ソー ト「リンゴ」を単項述語に使って「リンゴ $(c$ : 果物 $)\lrcorner$ が 「果物 $c$ がリンゴである」を示す .

\section{$2 \cdot 2$ rigidity $の$ 導入}

Guarino と Welty [Guarino 00b] による形式オントロ ジーの property 分類に基づいて, 順序ソート論理のソー 卜項やソート階層について再考する.文献 [Kaneiwa 04d] で提案されているように, 表 1 は本質属性, 非本質属性お よび非ソートに区別される property が, タイプ $\tau$ [Guarino 00a], 反 (anti-)rigid ソート $\sigma$ および単項述語 $p$ に対応づ けられていることを示す.これにより，インスタンス言明 (即ち，項 $t$ が property の実体である ${ }^{* *}$ ) が異なって意味 づけされる. タイプのインスタンス言明 $\tau(t)$ は, 項 $t$ が 常に $\tau$ に属すことを意味する .なぜならば，すべてのタ イプは rigid な性質を持つからである. 対して, rigid な性 質を持たない反 rigid ソートのインスタンス言明 $\sigma(t)$ お よび, 単項述語の言明 $p(t)$ はモデルに依存して成り立つ. 例えば，「人間」をタイプ，「学生」を反 rigid ソート， 幸せ」を単項述語とする.このとき, 述語論理式「人間 ( 太郎)」は常に真であると言えるが, 述語論理式「学生 ( 太郎)」と「幸せ (太郎 $) 」 の$ 真偽は時間や状況によって変 わる可能性がある.

順序ソート論理では, property 間の包攝関係(ある property が別の property を包攝する) を, サブソート関係と包 含 $(\Rightarrow)$ の 2 通りで表すことができる. サブソート関係を

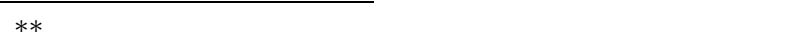
「property の実体」は，いずれも意味的にはある概念の実体や 個体を示している。
} 
使つた場合 , タイプと反 rigid ソートによる関係 $\tau_{1}<\tau_{2}$, $\sigma_{1}<\tau_{2}$ および $\sigma_{1}<\sigma_{2}$ が表現できて，この関係は常に 真となる . また，単項述語の包含関係は $p_{1}(x) \Rightarrow p_{2}(x)$ で表され，ある時間や状況にのみ成り立つ. 例えば, サ ブソート関係「人間 <動物」は常に成り立つが，「金持 ち $(x) \Rightarrow$ 幸せ $(x)\lrcorner$ は状況に依存して产の真偽値が決ま る.故に, $s_{1}, s_{2}$ のサブソート関係に rigid 性質を持たせ るためには，包含関係 $s_{1}(x) \Rightarrow s_{2}(x)$ で表すのは十分な 方法ではないことを示している*†.さらにオントロジー的 な分析によると，「学生＜人間」は反 Rigidソートが，タ イプのサブソートであると宣言されているので, タイプ 間の関係「人間 <動物」と同じように扱うのは誤りであ る。例えば，太郎が途中で学生を辞めても，弚のまま人間 であることを考慮する必要がある.加えて, 文献 [Guarino 00b]で述べられているように， $\tau<\sigma$ 形式のサブソート 関係 (即ち , タイプが , 反 Rigidソートのサブソートであ ると宣言されている) は, property の rigidity により許さ れない .これは，常に真とはならない反 rigidソートが常 に真となるタイプの上位ソートとなるのは，意味的に成 り立たないからである .

以上の仕樣を論理言語の形式化に反映されるために, ソート述語付きの順序ソート論理 [Beierle 92, Kaneiwa 04a] を基本言語に用いる. この論理は, 単項述語の論理 式 $p(t)$ を記述するとき，すべてのソートに対応する単項 述語 $p_{s}$ (ソート述語と呼ぶ）㛙を備えている.本研究では， タイプ $\tau$ と反 rigid ソート $\sigma$ を区別し光れらのソート述語 $p_{\tau}, p_{\sigma}$ を導入して, ソート表現におけるタイプ, 反 rigid ソートおよび単項述語の rigidity を注意深く扱う．通常 の順序ソート論理では, ソート $s$ の变数 $x$ は $x: s$ によっ て表し, ソート $s$ の定数 $c$ は $c: s$ によって表す. 光れに 対して property 分類を考慮した場合，タイプと反 rigid ソートの変数 $x: \tau, x: \sigma$, およびタイプ付きの定数 $c: \tau$ は許されるが, 反 rigid ソートの定数 $c: \sigma$ は禁止される

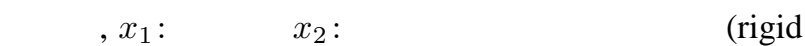
ソート)「人間」と反 rigidソート「学生」の変数を表し， 「太郎: 人間」はタイプ「人間」の定数を表す. しかし反 rigid ソート付きの定数 $c: \sigma$ は意味を成さない表現とし て排除される.例えば，太郎は永遠に学生ではないので， 「太郎：学生」は適切な表現とは言えない．即ち，反 rigid ソートの要素は流動的なので, 状況によってある要素が炎 の反 rigid ソートに属さないかもしれないのである . 従っ て反 rigid ソートに関しては, 变数のソート $x: \sigma$ とソー 卜述語 $\sigma(t)$ (または $\left.p_{\sigma}(t)\right)$ を用いることか望ましい. 例 えば次の論理式は, 反 rigid ソート「学生」か変数 $x$ の ソートを表す．

$$
\text { 優秀 }(x: \text { 学生 }) \Rightarrow \text { 奨学生 }(x: \text { 学生 })
$$

\footnotetext{
*† ここで問題にしているのは，包捸関係の rigidity であり property の rigidity ではない

*‡ ソート述語 $p_{s}$ は，混乱を招かない限り簡潔に $s$ で表す
}

また，論理式「学生 (太郎: 人間)」ではソート述語とし て使われる.

ソートシグネチャは定数, 関数と述語のソートを宣言す ることから , 以上の rigidity の考えに基づかなければなら ない. 定数 $c$ と関数 $f$ のソート宣言は, 弚れ光れ $c: \rightarrow \tau$ と $f: \tau_{1} \times \cdots \times \tau_{n} \rightarrow \tau$ のように，タイプによって宣言 される.述語に関しては, $p: s_{1} \times \cdots \times s_{n}$ のように任意 のソート (タイプまたは反 rigid ソート) で宣言すること ができる．しかし，ソート述語の宣言については少し注 意が必要である . Beierle ら [Beierle 92]が定義するソー 卜述語は，最大ソート丁によって宣言されていた (即ち， $\left.p_{s}: \top\right)$. 本研究では, 各ソートに対して, 本質属性の場 合には光のソートに分類される前のより抽象的な概念が 存在し，反 rigid ソートの場合には谷のソートを担い得る 概念が存在すると考える*§，例えば，タイプ「人間」に 対して「動物」であったり，反 rigidソート「学生」に対 して「人間」であったりする .これらの概念は通常光の ソートの上位ソートであるため, 一種の必要条件とみな すことができる．一方，非ソートに分類される property には特定の基本概念を決めることが容易ではない，もし くは決めることができても光の基本概念は非ソートかも しれない . 例えば，「赤い」の基本概念は「もの」かもし れないが赤い光を考えたとき「光」はものかどうか決め 難い，また「水」の基本概念「物質」は非ソートである． 従って，非ソートの述語では, ソートなしの宣言を許す べきである (例えば, $p:$ undef) .

\section{$2 \cdot 3$ 関数と 2 項述語への拡張}

property の名前に注目して, property か関数や 2 項述 語の名前に利用される場合の特性について分析する.文献 [兼岩 04c] では 1 つ名前を関数や 2 項述語などに適用 した場合に論理的な矛盾を回避する方法を述べているが， 本節では形式オントロジーの依存性に基づいて , property をどのようにして関数や 2 項述語の名前に適切に利用す べきかを新たに提示する．ここで重要なのは，前節では 形式オントロジーの考えを順序ソート論理の形式化に組 み込んで規定しているが，本節では形式オントロジーに 基づいてどのように論理式を記述するかのガイドライン を提示している.

順序ソート論理では, property は個体の集合としての ソートや単項述語に対応しており，弚の表現 (もしくは名 前) を同名の関数と 2 項述語へ拡張する方法を考える .も ちろん通常の論理言語では, ソート, 関数と述語の間で 同じ記号が使われることはない .ここで例として , ソー 卜「父親」を考えてみよう，一郎が子供を持ち，关の名 前を太郎と仮定する。

\section{〔 例 1〕（関数と 述語の表現）}

*§ 文献 [溝口 99] では, 基本概念は「夫」の場合の「男性」や 妻」の場合の「女性」の樣な，ロールを担いうる firstness を 持つ実体と定義されている。 

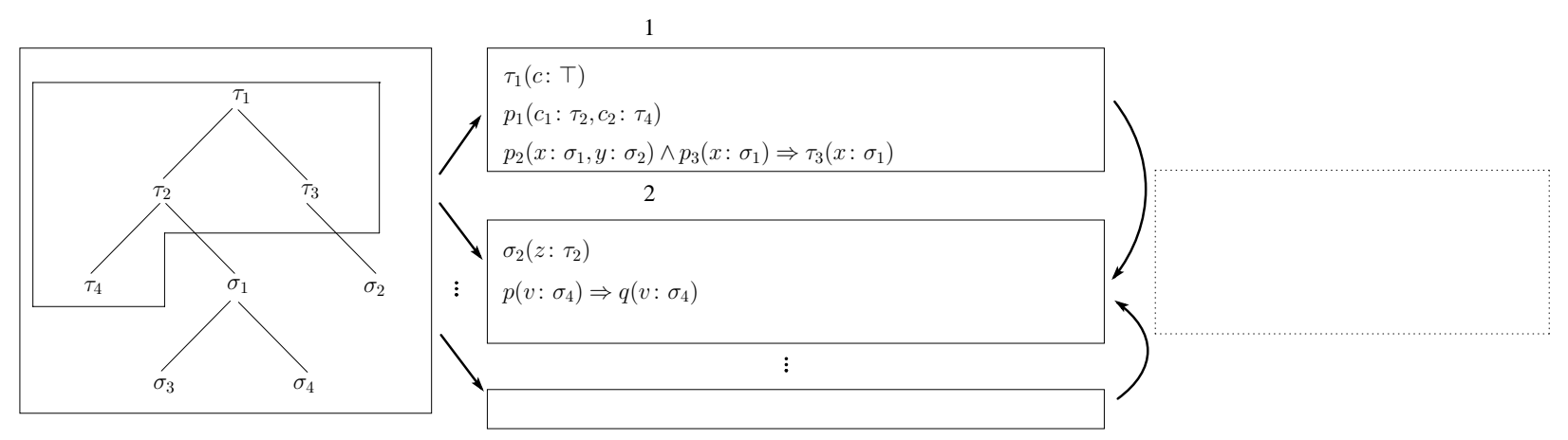

図 2 概念階層と複数の知識ベース

父親 (一郎) : 単項述語

父親 $($ 太郎 $)=$ 一郎 : 単項関数

父親 (一郎, 太郎)：2 項述語

このとき一郎は父親なので, 単項述語「父親 (一郎)」が 成り立つ．さらに同名の関数を考えると，太郎の父親は 一郎なので「父親 $($ 太郎) $=$ 一郎」が真となる．弚れによ り，単項述語「父親 (父親 (太郎))」と2 項述語「父親 (一 郎, 太郎)」も成り立つ．このとき，前者において外側の 「父親」は単項述語で, 内側の「父親」は単項関数である. 後者の意味は，「一郎は太郎の父親である」となる．

では，このような名前の利用が許されるのはどのよう なときであろうか? まず準備として，2つのソート間の 依存性を定義する . $s_{1}, s_{2}$ をソートとする . ソート $s_{1}$ の すべてのインスタンス $d_{1}$ に対して,$s_{2}$ のあるインスタ ンス $d_{2}$ が必然的に存在し， $d_{2}$ は $d_{1}$ の部分でも構成要素 でもないとき， $s_{1}$ は $s_{2}$ に依存するという .ここで， $d_{2}$ は $d_{1}$ に対する依存物と呼び，依存するソートを持つソー トのことを依存ソートと呼ぶことにする . 例えば上記の 場合, ソート「父親」はソート「子供」に依存している と言える . 父親のインスタンスは子供のインスタンスが 必ず存在しなければ成り立たない，即ち，父親のインス タンスである「一郎」には，子供のインスタンス「太郎」 が存在していた .

この依存性は Guarino と Welty [Guarino 00b] の定義 をソートに応用したものであるが, 本論文ではさらに依 存性が 2 項関係や単項関数にどう影響するか分析する. まず，2 項関係に関して次のように定義する .すべての 依存ソート $s$ に対して,$s$ と同名の 2 項関係 $r$ が存在し， 以下のような公理が成り立つ。

公理1: $(\forall x)(s(x) \Rightarrow(\exists y) r(x, y))$

例えば，ソート「父親」は依存ソートなので, $(\forall x)($ 父 親 $(x) \Rightarrow(\exists y)$ 父親 $(x, y))$ が成り立つ .これにより，例 えば上記の例で, 単項述語「父親 (一郎)」が 2 項述語 $\ulcorner(\exists y)$ 父親 (一郎, $y) 」($ 具体的には，「父親 (一郎, 太郎)」) を導く．成り立たない例として，ソート「動物」がある． 動物のすべてのインスタンスは, どのソートのインスタ ンスにも依存することなく存在する . 従って , 単項述語 「動物 (ポチ)」は許されるが , 依存する対象が無いので 2
項述語「動物 (ポチ,?)」はありえない表現と言える．さ らに, 関数に関しては依存性を拡張して, (i) ソート $s_{1}$ が あるソート $s_{2}$ に依存する , かつ (ii) $s_{1}$ のすべてのインス タンスは光れ光れ異なる依存物しか持たないならば， $s_{1}$ は $s_{2}$ と単一的な依存関係をもつという.あるソートと単 一的な依存関係をもつ持つソートを, 関数的依存ソート と呼ぶ.すすへての関数的依存ソート $s$ に対して,$s$ と同 名の単項関数 $f$ が存在し, 以下のような公理が成り立つ.

公理2 : $(\forall x)(s(x) \Rightarrow(\exists y) f(y)=x)$

例えば,父親」は関数的依存ソートとなる．しかし「祖 先」は依存ソートであるが関数的依存ソートではない .

\section{3. 本質属性に関する知識ベース推論}

文献 [Kaneiwa 04d] で提案された, タイプ, 反 rigid ソー 卜と単項述語の rigidity，およびソート階層を扱った知識 ベース推論について述べる. property の rigidity は , イ ンスタンス言明や包摂関係の意味に影響し，複数の知識 ベースにおける推論に反映される. 図 2 は , 光れ光れの 状況で独立して構築された複数の知識ベースと，タイプ 階層とソート階層を示している .このとき, 各知識ベース は階層に含まれるソートとタイプを共通して利用できる と仮定する . また推論に関しては, 各知識べースの中で 閉じていると考えるのが妥当である．しかし情報が本質 属性であると認識できれば，他の知識べースから光の情 報を抽出することが可能になる . 次に挙げる複数の知識 ベースと図 3 のタイプ階層とソート階層を使って, 知識 ベース間でどのように property 情報の導出が可能か説明 する .

知識ベース 1:

(1a) 男子学生 (太郎: 人間),

(1b) 優秀 (太郎: 人間),

(1c) 優秀 $(x:$ 学生 $) \Rightarrow$ 奨学生 $(x:$ 学生 $)$

知識ベース 2:

(2a) 教師 (花子: 人間),

(2b) 好き (花子: 人間, $x$ : 学生),

(2c) 好き (花子: 人間, $x$ :鳥)

知識ベース 3: 


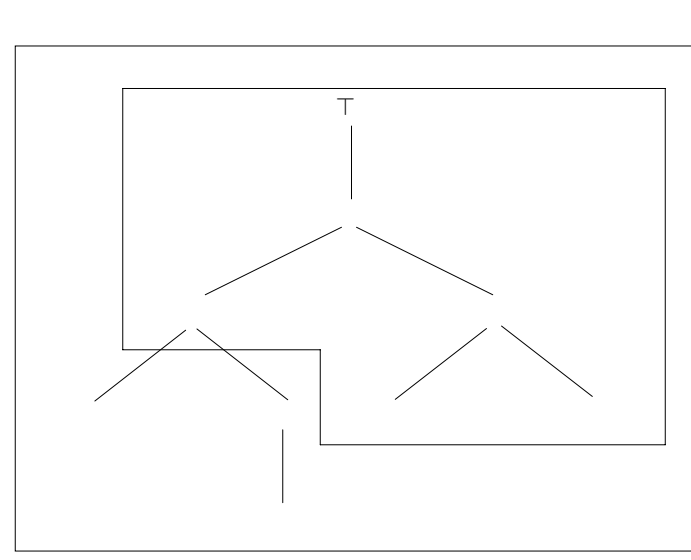

図 3 タイプ階層とソート階層

(3a) カナリア (次郎: 動物),

(3b) 鳥 $(x:$ 動物 $) \Rightarrow$ 飛べる $(x:$ 動物 $)$

知識ベース 4:

(4a) 父親 (一郎: 動物, 次郎: 動物),

(4b) 父親 ( $y$ : 動物, $x$ : 動物)

$$
\wedge \text { 鳥 }(x: \text { 動物 }) \Rightarrow \text { 鳥 }(y: \text { 動物 })
$$

最初に知識ベース 3 がインスタンス言明 (3a) を含んで いるとき，サブソート関係「カナリア<鳥」が成り立つ ので, 「鳥 (次郎: 動物)」が知識ベース 3 て導出される.こ の結果は，同樣に他の知識ベースでも成り立つ．なぜな らば，タイプ「鳥」の要素は特定の状況に依存しないで 解釈されるからである (即ち,「鳥」は rigid である)，言 い換えると, タイプ「鳥」の要素は, 反 rigidソート「学 生」などとは違って固定されているため, 次郎が鳥であ ることが常に成り立つ. 従って, 本質属性の情報として のインスタンス言明はすべての状況で真になり，「鳥 (次 郎: 動物)」は広域的に知識ベース 1,2 および 4 でも真と なる.この情報の拡張によって, 知識ベース 2 は新たに 「好き (花子: 人間, 次郎: 動物)」を (2c) から導くことが できる .これは, 従来の本質属性の情報を抽出しない方 法では導かれなかった結果である. さらに知識べース 4 は, 事実 (4a)および規則 (4b) から「鳥 (一郎: 動物)」を 導く.この事実も本質属性の情報であり，知識ベース 3 で「飛べる (一郎: 動物)」を再帰的に導いて, 知識ベー ス 2 で「好き(花子: 人間,一郎: 動物)」を導くことがで きる. 最初に知識ベース 3 は本質属性の情報を知識ベー ス 4 へ伝達し, 光の後新しい事実が知識ベース 4 で導か れる. 光の結果，逆に知識べース 3 が炎の事実を本質属 性の情報として知識ベース 4 から抽出するので再帰的な 導出となる .一方, インスタンス言明 (1a) とサブソート 関係「男子学生 <学生」が成り立った場合には,「学生( 太郎: 人間)」は知識ベース 1 でしか成り立たない，なぜ ならば,「学生」は rigid ではないからである. 故に, 知識 ベース 3 が $(2 b)$ から「好き(花子: 人間, 太郎: 学生)」を 導くことはできない .

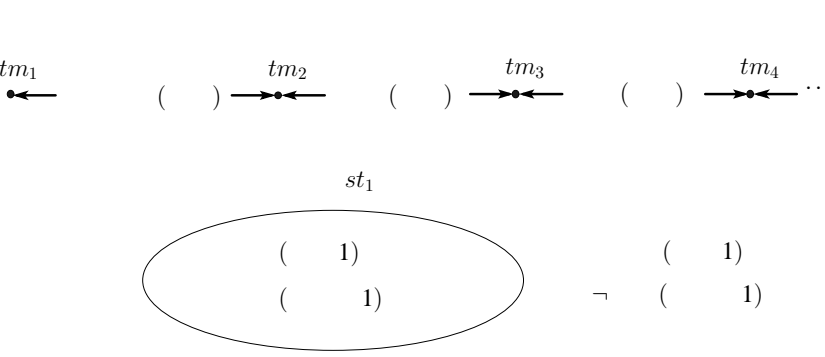

$<$ 時間·状況依存 $>$

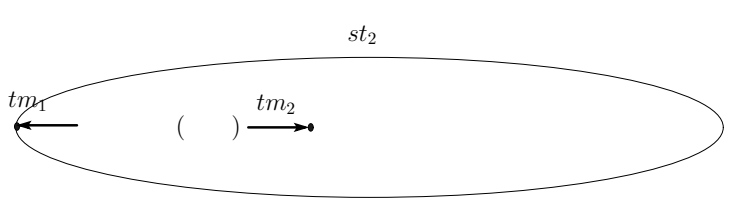

図 5 時間と状況の依存性

\section{4. property の意味論}

ここまでに述べた property の区別に基づいて，可能世 界上の意味解釈と光れによる property の細分化について 考える.特に，文献 [Kaneiwa 04d] では扱われていない 非本質属性と非普遍特性などの意味論による分類を提案 し, Guarino と Welty [Guarino 00b] の property 分類を精 緻化する .

\section{$4 \cdot 1$ 非本質属性の分類}

まず, property の rigidity を特徵付けるために, 可能世 界 $w_{i}$ の集合 $W$ を含んだクリプケ意味論を用いる．Uを 個体の全体集合， $R$ を $W \times W$ 上の到達可能性関係， $I=$ $\left\{I_{w} \mid w \in W\right\}$ をすべての世界 $w \in W$ に対する解釈関数 $I_{w}$ の集合としたとき， $M=(W, R, U, I)$ をモデルと呼ぶ . このとき，ソート記号 $s$ は，各世界 $w$ において $I_{w}(s) \subseteq U$ と解釈され，サブソート関係 $s_{i}<s_{j}$ は $I_{w}\left(s_{i}\right) \subseteq I_{w}\left(s_{j}\right)$ と解釈される .反 rigidソートと違って, タイプは rigidな のですべての世界 $w_{i}, w_{j} \in W$ に対して $I_{w_{i}}(\tau)=I_{w_{j}}(\tau)$ が成り立たなければならない.ささらに定数と関数のソー 卜は rigid であるので, すべての世界 $w_{i}, w_{j} \in W$ に対し て $I_{w_{i}}(c)=I_{w_{j}}(c)$ かつ $I_{w_{i}}(f)=I_{w_{j}}(f)$ となる. 加え て, 各世界 $w$ においてソート $s$ と产のソート述語 $p_{s}$ の 解釈は同一になる (即ち, $I_{w}(s)=I_{w}\left(p_{s}\right)$ ).

以上の意味づけは，従来の順序ソート論理にはない property の rigidity を内包的に解釈している.これに基づ いて異なる種類の可能世界として時間および状況を導入

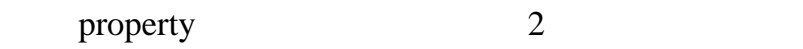
理や推論などで特別に扱われており， property の特徵を捉 えるためにも重要な要素と考えられる . 時間 $t m_{i}$ の集合 をTim，状況 $s t_{i}$ の集合をSit で表し，Tim $\cup$ Sit $\subseteq W$ とする.よって先の解釈において, rigid なソートか時間/ 状況のいずれにも依存しない性質は保持される．次の例 は，非本質属性 (反 rigid ソート)を，時間と状況に依存 して成り立つかどうかで分類している(図 4). 


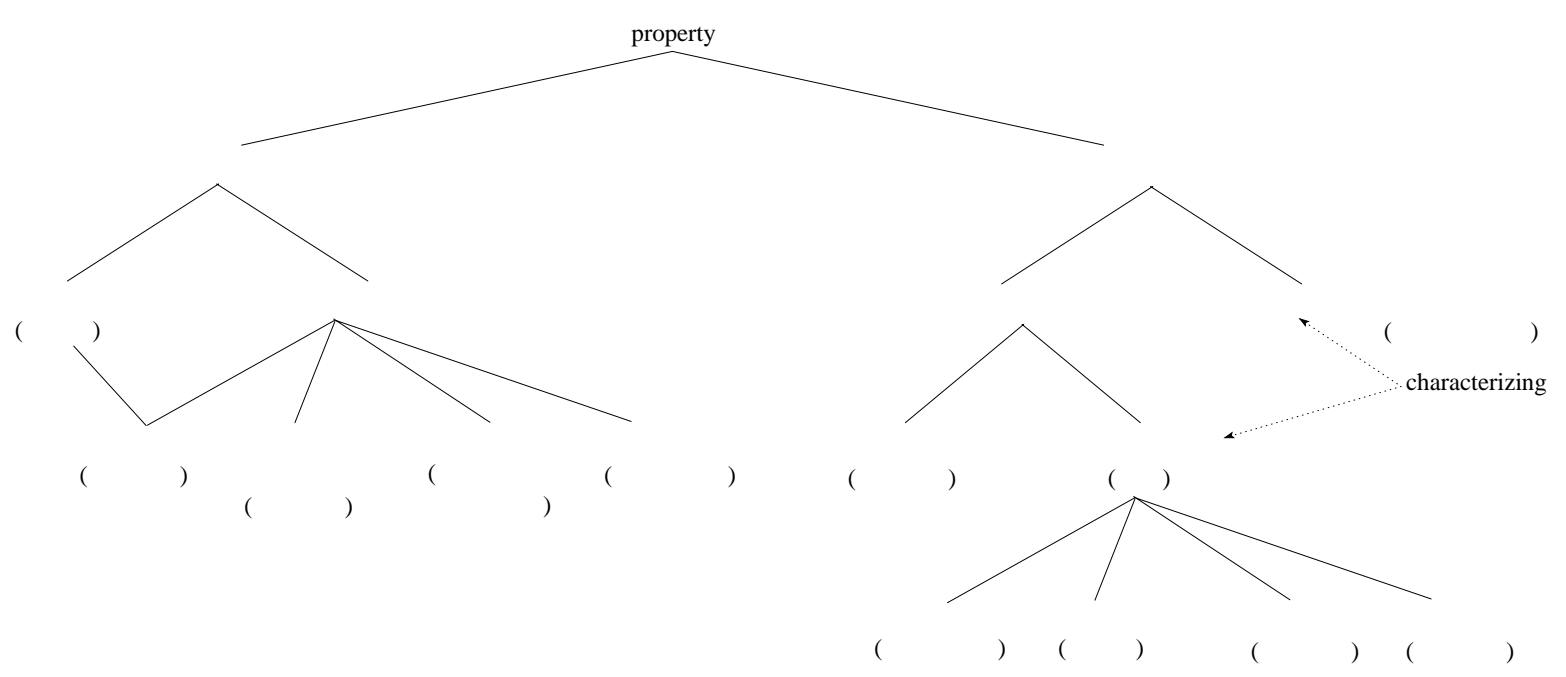

図 4 property の分類木 (b)

\section{〔 例 2〕（時間と状況の依存性）}

赤ちゃん，子供，青年，成人，老人：時間依存

武器, 机, 歩行者: 状況依存

新人教師, 中堅社員 : 時間・状況依存

直観的には，時間依存は時間だけに依存する，もしく は本質的に時間で決まる依存性であり，状況依存とは状 況には依存するか時間には依存しないことである．しか し具体物の存在全ては時間に関わっている (関係がある) と考えるのが妥当である. 兴のため本論文では, 時間と の「依存」と「関わり」を区別して単なる時間との関わ りを時間依存とは言わない . 故に , 状況依存は時間に関 わってはいるが, 依存してはいないとする．さらに，時 間・状況依存は，時間にも状況にも依存することを意味 する .これらの依存性は，次のように明確に定義される． 時間依存：実体が存在する期間の内ある限定した期間で のみ property が成り立つとともに，弚の期間でのすべて の状況でも property が成り立つ.

状況依存：ある状況でのみ property が成り立ち，兴の状 況下では任意の時間で property が成り立つ．

時間・状況依存：ある状況でのみ property が成り立つと ともに, 弚の状況下の限られた期間でのみ property が成 り立つ.

图 5 で示されているように,最初の例「赤ちゃん」など は，時間に依存して実体が关の property をもつかどうか すべてが決まる「武器」などは本質属性 (タイプ) として のソートとは別に, 単項述語として考えた場合, 状況に 依存する property と考えられる(しかし，時間には影響 せず「武器」であることが言える)．興味深いことに，「武 器」と「机」の実体は, 拳銃や学習机のようにはじめから 兴の役割をもつものと,ナイフやみかん箱のように後か ら光の役割をもつことがある(厳密には人工物兴のもので はなく「机」と呼ばれるだけであって，机として作られた 机ではない). 後者の場合，みかん箱を机として使う状況 においてのみ兴の propertyが成り立つ．順序ソート論理
において，前者はソートのインスタンスとしての武器で， 後者は単項述語「武器」が示す性質を満たした実体を意 味する .このとき，これまでのソートと炎のソート述語が 等しく解釈されていた事実か覆されて, $I_{w}(s) \subsetneq I_{w}\left(p_{s}\right)$ となる. 例えば, 学習机 $1 \in I_{w}($ 机 $) \cap I_{w}\left(p_{\text {机 }}\right)$ であるが, みかん箱 $1 \notin I_{w}($ 机 $)$ かつ みかん箱 $1 \in I_{w}\left(p_{\text {机 }}\right)$ となる. 3つ目の「新人教師」などは, 時間にも状況にも依存して 成り立つ概念である. 新人かどうかは時間で決定されて， 教師かどうかは教師をしている状況に依存するため，あ る状況下でしかも特定の時間内でのみ成り立つと言える . 時間と状況の依存性は, 可能世界によって次のように意 味論で定義される.すべての時間 $t m_{i}, t m_{j} \in \operatorname{Tim}$ に対し て $I_{t m_{i}}(p)=I_{t m_{j}}(p)$ であるとき, property $p$ は任意の時 間で成り立つという.ある時間 $t m_{i}, t m_{j} \in T i m$ が存在し て,$d \in I_{t m_{i}}(p)$ かつ $d \notin I_{t m_{j}}(p)$ であるとき, property $p$ はある時間で成り立つという.この定義は，すべての 可能世界で同じ実体 (個体) が存在することを仮定してい

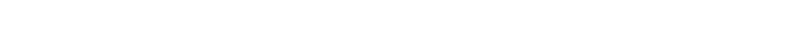
の可能世界では違って実体が存在するかもしれない . 即 ち, 可能世界 $w$ での個体の全体集合を $U_{w}$ で表すと，光 れは別の可能世界 $w^{\prime}$ の個体の全体集合 $U_{w^{\prime}}$ とは一致し ない . 例えば,「人間」の各実体はすべての時間で存在す ることはあり得ない．よって定義し直すと，すべての時 間 $t m_{i}, t m_{j} \in \operatorname{Tim}$ に対して,$d \in U_{t m_{i}} \cap U_{t m_{j}}$ のとき， $d \in I_{t m_{i}}(p) \Leftrightarrow d \in I_{t m_{j}}(p)$ が成り立つならば， property $p$ は任意の時間で成り立つという.$d \in U_{t m_{i}} \cap U_{t m_{j}}$ と なる時間 $t m_{i}, t m_{j} \in \operatorname{Tim}$ が存在して,$d \in I_{t m_{i}}(p)$ かつ $d \notin I_{t m_{j}}(p)$ であるとき , property $p$ はある時間で成り立 つという . 状況についても同樣に定義できる .

時間依存 (状況依存)であるとき property は状況 (時間) には依存しないことや, 時間にも状況にも依存する時間・ 状況依存を意味づけするには, 時間と状況とがどのように 関係して产の依存性が決まるかを定義しなければならな い.ここで可能世界上の到達可能性関係 $R \subseteq W \times W$ を 
用いて，時間と状況との関係を以下のように意味づける．

(1) tmRst：時間 $t m$ が状況 st に到達可能であるこ とを示し，st は時間 $t m$ における状況である .

(2) stRtm: 状況 st が時間 $t m$ に到達可能であるこ とを示し,$t m$ は状況 $s t$ における時間である .

これらの解釈関数と到達可能関係によって, $p$ が property であるとき依存性の意味論は, 次のように与えられる .

・時間依存のとき，ある期間 $t m_{i}$ から $t m_{j}$ で成り立 つ，および $d \in I_{t m}(p)$ ならば時間 $t m$ から到達可能 なすへてての状況 $s t \in S i t$ において $d \in I_{s t}(p)$ である .

- 状況依存のとき，ある状況 st で成り立つ，および $d \in I_{s t}(p)$ ならば状況 st から到達可能なすべての時 間 $t m \in \operatorname{Tim}$ において $d \in I_{t m}(p)$ である.

- 時間・状況依存のとき，ある状況 st で成り立つ，およ び $d \in I_{s t}(p)$ ならば状況 $s t$ から到達可能なある期間 $t m_{i}$ から $t m_{j}$ 内の時間 $t m$ においてのみ $d \in I_{t m}(p)$ である .

文献 [Kaneiwa 05b]では , 時間と状況の依存性とともに， この到達可能関係に対応する樣相演算子か導入され，順 序ソート付きの樣相論理の構文, 意味論および推論シス テム (タブロー法) が設計されている .

可能世界の種類によって依存性を分析する利点は，反 rigid な property の意味論を精緻化できることにある rigidity と依存性の種類の組み合わせによって, property を解釈するときにすべての可能世界ではなくて特定の可 能世界 (例えば，時間) で rigidity を意味づけできる . 例 えば，太郎が赤ちゃんであるとき，光の事実は時間に依 存するので, 乥れが成り立つ時間内では状況が変わって も，太郎は常に赤ちゃんである . 厳密には, 太郎 $\in I_{t m_{1}}($ 赤ちゃん）ならば，時間 $t m_{1}$ から到達可能なすべての状 況 $s t_{i}$ に対して，太郎 $\in I_{s t_{i}}$ (赤ちゃん) が成り立つ.

以上に加えて, 次の非本質属性「親切」と「美人」は 時間や状況ではなく人の見方・感じ方に依存して決まる 性質として，信念依存と呼ぶ”。

\section{〔 例 3]（信念の依存性）}

親切, 美人 : 信念依存

このような依存性は, 客観性が深く関係している. 例え ば，図 6 のように「親切」や「美人」は主観的な価値観 であるが、大男」や「こびと」は大多数の信念で成り立 つ客観的で安定した性質と言える。しかし，こうした客 観性の比較を可能世界で扱うのは困難なため, 本論文で はこの意味づけを行わず今後の課題とする .

\section{$4 \cdot 2$ ソートと非ソート}

次に , ソートと非ソートについて分析する . 形式オン トロジーでは, ソートは光の実体の部分が光の property を持たず(例えば，「人間」の部分は人間ではない)，各実 体が identity を認識できる property である．乥うでなけ れば，非ソートである .さらにソートの実体は「人間」 のように何人であるか数えられるが, 非ソートの実体は
<信念依存 >

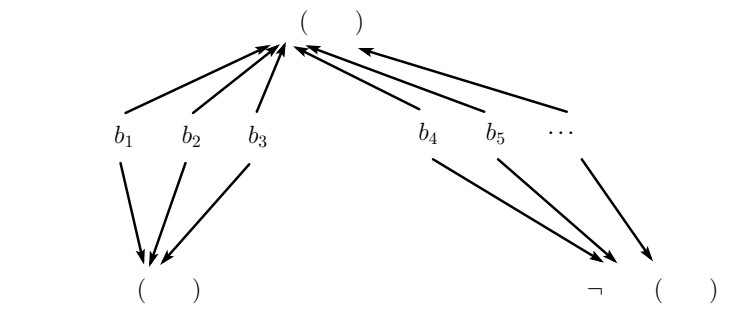

図 6 信念の依存性

「水」のように容器や特定のかたまりの単位て数えられる.

〔 例 4] (ソートと非ソート )

人間, 学生 : 部分が全体と違う, 数えられる

水, 空気: 部分が全体と同じ, 容器などて数えられる 本研究では, ソートと非ソートの中間的な分類が必要性 であると考える「水」のように部分が全体の property を 持つ(「水」の部分も水である) 場合を，特に反ソートと 呼ぶ．また，「大きい」のように部分が光の property を 持ったり持たなかったりする場合を，準ソートと呼ぶ .

〔 例 5]（準ソート）

大きい, 長い: 部分が全体と違う, 数えにくい

例えば, 大きいものの半分はまだ大きいかもしれないが， 兴の 20 分の 1 の部分はもはや大きくないかもしれない . 即ち, 全体の中で光の property を特徵付けている境界が 存在するわけである. しかし关の境界が暧昧なために数 えにくい概念とみなされる .

図 4 のように反ソートを rigidity により分類すると， rigid な反ソートは普遍特性と呼ばれ, 非 (non-)rigid は非 普遍属性と呼ばれる.非普遍属性と準ソートはともに非 rigid な非ソートとして characterizing と呼ぶ . 普遍属性， 非普遍属性と準ソートの例は，以下の通りである .

\section{〔 例 6]（非普遍属性と準ソート）}

水, 空気: rigid，反ソート

赤い: 非 rigid，反ソート, characterizing

大きい, 長い: 非 rigid，準ソート , characterizing 特に反ソートに関しては, 次の事実か導かれる .ここで 実体 $d_{1}$ が実体 $d_{2}$ の部分であることを，部分関係 $d_{1} \prec d_{2}$ で表す .このとき，反ソート $p$ に関しては,$d_{2} \in I_{w}(p)$ ならば $d_{1} \in I_{w}(p)$ であることが成り立つ. 例えば、「コッ

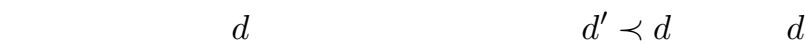
の部分 $d^{\prime}$ も「水」であることが言える .

さらに，非普遍特性「赤い」は，Guarino ら [Guarino 94]の研究ではリンゴの色, 深紅色が属す色系, および共 産主義者としての赤として 3 種類に分類されている . 本 論文では独自に，先に述べた時間と状況の依存性によっ て「赤い」の多樣性を分析する「赤い」をソート付き論

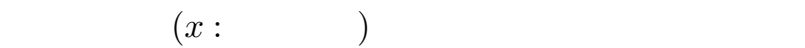
い $(x) \wedge$ property 名 $(x)\lrcorner$ のうにソートや property に よって対象を限定すると，以下のように分類できる (図 4) . 


\section{〔 例 7〕 (「 赤い」の多様性)}

赤い $(x:$ リンゴ) : 状態 , 時間依存

赤い $(x:$ 顔 $):$ 状態, 状況依存

赤い $(x:$ バラ $):$ 種別, 本質属性

赤い $(x) \wedge$ 物質 $(x)^{* \text { 【 }}$ :色, 非ソー卜

最初の例の「赤い $(x:$ リンゴ $)\lrcorner$ は , リンゴがはじめは 黄色くてだんだん熟してきて赤くなるリンゴの状態を意 味しているので, 子供 , 大人 , 老人と同じ時間依存と言え る (紅葉なども同じ部類に入る) . 2つ目の「赤い $(x:$ 顔 )」は，恥ずかしいと赤面する場合の「赤い」状態である が , これは状況依存であるので1つ目と違う種類に属す．

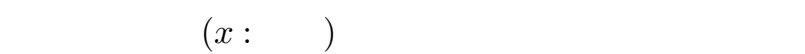
の種類の違いを示す「赤い」である．よって，バラの中 での種類を表すという意味で本質属性と言える . 最後の $\ulcorner$ 赤い $(x) \wedge$ 物質 $(x)\lrcorner$ は少々考察が必要である . バラの 場合は，バラという植物種が特定された後での property 分類の詳細化であることから光の色が本質という議論が できる．一方，一般の物質は色以前に物質構成において もつと本質的な property があると思われ，これは「物質」 と同樣に非ソートに分類される .

以上の議論では,「赤い」の property を持つ対象をリン ゴ , 顔 , バラなどに特定すると，面白いことに rigidityや 兴の他の性質が変わることが分かる. 兴のような対象の 特定による property 分類は, ソート記号によって項表現 のドメインを限定している順序ソート論理と相性がいい と考えられる. 即ち, 順序ソート論理への応用に向いて いるのである .

加えて, 本論文では触れていない依存性 (時間依存性 などとは関わりか溥い)として , 文化依存を考えると , 国 によって色の違う郵便ポストや消防自動車のようなもの， 或いは日本では赤色が赤信号のように「禁止」や「危険」 を意味するが中国では「幸福」を表すようなものが，「赤 い」の特別な性質として考えられる．

このように property の意味論を形式的に定義するのは， 知識ベースなどに記述された property に関する知識が整 合的であるか判定したり，谷の知識からの推論の安全性 を保障したりするのに役立つからである．例えば， 3 章 の推論アルゴリズムを定義したとき, 光れが安全である か証明できる.さらに，可能世界の種類による意味論は， 知識の整合性に厳しい条件を与えているとも言える。 うしたソート表現や論理表現に制約を加えて, 知識の整 合性を判定するアプローチ [兼岩 04c, Tun 04] があるが， それらは本研究に比べると順序ソート論理と形式オント ロジーの融合に関して不十分であった .

\footnotetext{
$*$ 『「物質」は非ソートなので,「赤い $(x:$ 物質 $)\lrcorner$ の表現は許さ
} れない .

\section{5. おわりに}

本研究では, 形式オントロジーの属性分類を用いるこ とで順序ソート論理の構文や意味論を再考し, 複数の知 識ベースによる推論を提案した. 順序ソート論理の拡張 では, 3 種類の property (タイプ, 反 rigid ソートおよび単 項述語) を区別した上で，インスタンス言明と包捸関係 $(\tau<\sigma$ を除く)の rigidity を考慮した形式化を行った. こ れらの拡張により, 複数の独立した知識ベース間の推論 において (共通の知識として)rigid な情報のやり取りを可 能にしている．また，1 つの property から炎れと同じ名 前の単項関数や 2 項述語を記述するための条件を, 形式 オントロジーに基づいたソート間の依存性によって定義 した。論理体系の拡張とは異なって，こうした property 名から関数や述語への応用は, 形式オントロジーによっ て記述者へのガイドラインを提示していると言える .

さらに , 順序ソート論理の意味論とクリプキ意味論に おいて，上記の 3 種類の property に対する rigidity を意 味づけした . 兴の意味論に基づいて, 状況/時間の可能世 界による依存性を定義し，关れ光れの依存性およびその 組み合わせによって非本質属性や非普遍属性を細分化し た . 非ソートには, 実体がどう数えられるかによって反 ソートと準ソートの区別を新たに取り入れている．

今後の課題として，本論文で新たに提案した property 分類を推論システムに組み込む拡張がある . 例えば, 状 況/時間の依存性からもたらされる property の推論を提 案することで, 知識の本質を捉えた推論メカニズムの実 現に役立つと考えられる．また，記述論理 [兼岩 03]や Web オントロジー言語 OWL[兼岩 05a] のようなよく知 られている概念言語の推論メカニズムに, 本研究の考え を応用することも検討中である .

\section{謝}

\section{辞}

本論文の改善にあたり，こ指摘をいただいた査読者に 感謝する.本研究の一部は, 文部科学省科学研究費補助 金 若手研究 (B) (課題番号 : 17700164) の助成を受けて いる。

\section{$\diamond$ 参 考 文 献 $\diamond$}

[Aït-Kaci 86] Aït-Kaci, H. and Nasr, R.: LOGIN: A Logic Programming Language with Built-In Inheritance, Journal of Logic Programming, Vol. 3, No. 3, pp. 185-215 (1986)

[Beierle 92] Beierle, C., Hedtsück, U., Pletat, U., Schmitt, P., and Siekmann, J.: An order-sorted logic for knowledge representation systems, Artificial Intelligence, Vol. 55, pp. 149-191 (1992)

[Cohn 87] Cohn, A. G.: A More Expressive Formulation of Many Sorted Logic, Journal of Automated Reasoning, Vol. 3, pp. 113-200 (1987)

[Cohn 89] Cohn, A. G.: Taxonomic reasoning with many sorted logics, Artificial Intelligence Review, Vol. 3, pp. 89-128 (1989)

[Frisch 89] Frisch, A. M.: A General Framework for Sorted Deduction: Fundamental Results on Hybrid Reasoning, in Proceedings of the First International Conference on Principles of Knowledge Representation and Reasoning (1989) 
[Guarino 94] Guarino, N., Carrara, M., and Giaretta, P.: An Ontology of Meta-Level Categories, in Proc. of the 4th Int. Conf. on the Principles of Knowledge Representation and Reasoning, pp. 270280 (1994)

[Guarino 00a] Guarino, N. and Welty, C.: A Formal Ontology of Properties, in Proceedings of EKAW-2000: The 12th International Conference on Knowledge Engineering and Knowledge Management, pp. 97-112 (2000)

[Guarino 00b] Guarino, N. and Welty, C.: Ontological Analysis of Taxonomic Relationships, in Proceedings of ER-2000: The Conference on Conceptual Modeling (2000)

[兼岩 03] 兼岩憲, 佐藤健 : レクチャーシリーズ「哲学と AI にお ける対象世界モデリング」〔第 6 回〕DL: Description Logics, 人 工知能学会誌, Vol. 18, No. 1, pp. 73 - 82 (2003)

[Kaneiwa 04a] Kaneiwa, K.: The completeness of logic programming with sort predicates, Systems and Computers in Japan, Vol. 35, No. 1, pp. 37-46 (2004)

[Kaneiwa 04b] Kaneiwa, K.: Order-Sorted Logic Programming with Predicate Hierarchy, Artificial Intelligence, Vol. 158, No. 2, pp. 155188 (2004)

[兼岩 04c] 兼岩 憲 : オントロジー構築に対する概念階層の整合 性, コンピュータソフトウェア, Vol. 21, No. 2, pp. 12-24 (2004)

[Kaneiwa 04d] Kaneiwa, K. and Mizoguchi, R.: Ontological Knowledge Base Reasoning with Sort-Hierarchy and Rigidity, in Proceedings of the 9th International Conference on the Principles of Knowledge Representation and Reasoning (KR2004), pp. 278-288 (2004)

[兼岩 05a] 兼岩 憲: 特集号〈セマンティック Web と計算機科学 > 「OWL の推論と光の計算量」, コンピュータソフトウェア, Vol. $22(2005)$

[Kaneiwa 05b] Kaneiwa, K. and Mizoguchi, R.: An Order-Sorted Quantified Modal Logic for Meta-Ontology., in Proceedings of the International Conference on Automated Reasoning with Analytic Tableaux and Related Methods (TABLEAUX 2005), pp. 169-184, LNCS 3702, Springer-Verlag (2005)

[Kifer 95] Kifer, M., Lausen, G., and Wu, J.: Logical Foundations of Object-Oriented and Frame-Based Languages, J. ACM, Vol. 42, No. 4, pp. 741-843 (1995)

[Lowe 89] Lowe, E. J.: Kinds of Being. A Study of Individuation, Identity and the Logic of Sortal Terms., Basil Blackwell, Oxford. (1989)

[溝口 99] 溝口理一郎, 池田満, 来村德信 : オントロジー工学基礎 論 - 意味リンク, クラス, 関係, ロールのオントロジー的意味 論 - , 人工知能学会誌, Vol. 14, pp. 1019-1032 (1999)

[Oberschelp 62] Oberschelp, A.: Untersuchungen zur mehrsortigen Quantorelogik, Mathematische Annalen 145, pp. 297-333 (1962)

[Smolka 89] Smolka, G.: Logic Programming over Polymorphically Order-Sorted Types., PhD thesis, Universitat Kaiserslautern. (1989)

[Strawson 59] Strawson, P. F.: Individuals: An Essay in Descriptive Metaphysics, Methuen, London (1959)

[Tun 04] Tun, N. and Tojo, S.: Consistency Maintenance in Ontological Knowledge Updating, in IEEE-Information Reuse and Integration (2004)

[Walther 85] Walther, C.: A Mechanical Solution of Schubert's Steamroller by Many-Sorted Resolution, Artificial Intelligence, Vol. 26, No. 2, pp. 217-224 (1985)

[Weibel 97] Weibel, T.: An Order-Sorted Resolution in Theory and Practice, Theoretical Computer Science, Vol. 185, No. 2, pp. 393410 (1997)

〔担当委員：池田 満〕

2004 年 9 月 27 日 受理

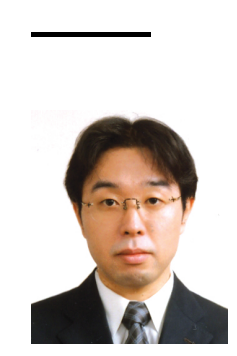

\section{者 紹 介}

\section{兼岩＼cjkstart憲(正会員)}

1993-1996 年富士通 (株) 勤務. 1998 年北陸先端科学技術 大学院大学情報科学研究科修士課程修了. 2001 年同大学 院情報科学研究科博士後期課程修了。現在，国立情報学研 究所情報学基礎研究系助手. 論理プログラミング,ソート 論理，知識表現およびオントロジーに関する研究に従事。 ソフトウェア科学会, 電子情報通信学会, 情報処理学会, ALP , ASL 各会員 .

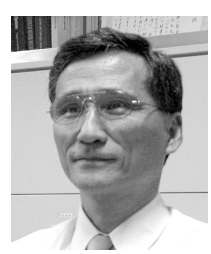

溝口 理一郎(正会員)

1972 年大阪大学基礎工学部電気工学科卒業. 1977 年同大 学院基礎工学研究科博士課程修了. 同年, 大阪電気通信大 学工学部講師, 1978 年大阪大学産業科学研究所助手, 19 87 年同研究所助教授, 1990 年同教授。現在に至る. 工学 博士 .パターン認識関数の学習, クラスタ解析, 音声の認 識・理解, エキスパートシステム, 知的 CAI システム オ ントロジー工学の研究に従事. 1985 年 Pattern Recognition Society 論文賞, 1988 年電子情報通信学会論文賞, 1996 年 人工知能学会創立 10 周年記念論文賞, 1999 年 ICCE99 Best paper Award 受賞。 Intl. AI in Education (IAIED) Soc. 及び APC of AACE の会長, 人工知能学会理 事, 同学会誌編集委員長, 電子情報通信学会論文誌編集委員, 教育システム情報 学会理事, 同学会誌編集委員長を歴任. 情報処理学会, 日本認知科学会, AAAI, IAIED Soc., APSCE 各会員. 現在, 人工知能学会副会長 . 